\title{
The Secular Beyond: Free Religious Dissent and Debates over the Afterlife in Nineteenth-Century Germany ${ }^{1}$
}

\author{
TODD WEIR
}

$\mathrm{T}$ OWARD the end of the first third of the nineteenth century, German writers began to favor a new metaphor for the afterlife: "das Jenseits" ("the Beyond"). ${ }^{2}$ At first glance, the emergence of such a term may appear to have little bearing on our understanding of the history of religious thought. However, as the late historian Reinhart Koselleck maintained, the study of semantic changes can betray tectonic shifts in the matrix of ideas that underpin the worlds of politics, learning, and religion. Drawing on Koselleck's method of conceptual history, the following essay takes the popularization of "the Beyond" as a point of departure for investigating secularization and secularism as two linked, yet distinct, sources of pressure on the fault lines of nineteenth-century German religious thought. ${ }^{3}$

\footnotetext{
${ }^{1}$ This article opens up for a broader audience research completed for a workshop on "The Transformation of the Belief in the Beyond in Modern History" at the Siemens Foundation in Munich on 17 May 2005. I am grateful to the workshop organizer, Lucian Hölscher, and the other participants for their helpful comments on the paper that has been published in conference proceedings as “'Keine Lücke mehr im Menschen, worin das Jenseits sich einnisten könnte,' Naturwissenschaft und Dissidenz in der frühen freireligiösen Bewegung," in Das Jenseits: Facetten eines religiösen Begriffs in der Neuzeit, ed. Lucian Hölscher (Göttingen: Wallstein, 2007), 95-122. Permission to use some of this material is here thankfully acknowledged. The present article benefited from the critical eyes of Tracie Matysik, at the University of Texas at Austin, and my colleagues Andrew Holmes and Emma Reisz at Queen's University Belfast.

${ }^{2}$ Note on translation. German terms have been translated except where no clear English equivalent could be found. This is the case for "freigeistig" (meaning both freethinking and free spiritual), "Deutschkatholiken" (the name of a Catholic dissenting group that it would be misleading to call "German Catholics") and "Diesseits" (the opposite of "Jenseits"). The German term "Jenseits" has been interspersed with "the Beyond" in order to remind the reader of the German specificity of the key term of this investigation. The main state church of Prussia, the "evangelische Kirche," has been translated as the "Protestant Church" rather than the "Lutheran Church" (its American denominational equivalent) because it was created through the merger of the Lutheran and Reformed churches (1817-1821). Unless otherwise noted, all translations are my own.

${ }^{3}$ Reinhart Koselleck, "Einleitung," in Geschichtliche Grundbegriffe: Historisches Lexikon zur politisch-sozialen Sprache in Deutschland, ed. Reinhart Koselleck, et al. (Stuttgart: Klett-Cotta, 1972), xii-xxvii. Reinhart Koselleck, The Practice of Conceptual History: Timing History,
}

Todd Weir is lecturer in modern European history at Queen's University Belfast. 
A comparison of the semantic qualities of "the Beyond" with those of older synonyms already points to secularization understood as the erosion of a clear distinction between the transcendent and the immanent spheres. "Heaven" (Himmel) and "the Kingdom of God" (das Reich Gottes) described the afterlife as a concrete place, while "eternity" (Ewigkeit) placed it in a separate temporality. "The Beyond" was, by contrast, purely relational, taking as its referent the world and the time of the living. This neologism brought the afterlife closer to this world and yet made its actual location more abstract and hence uncertain. The appearance of "das Jenseits" in the eighteenth century, and its wide popularization in the nineteenth century, correspond to the gradual secularization of Western Christian concepts of the afterlife described by church historians. ${ }^{4}$

A cursory look at the historical usage of "the Beyond" reveals secularism as a second dimension that must be accounted for. By the mid-1840s, the Beyond had become a central term over which deists, spiritualists, traditional Christians, and humanists articulated their differing conceptions of the nature of death. Koselleck found such polyvalence a defining quality of any key category (Grundbegriff) and one that allowed for the politicization of semantics. Debates over the meanings of categories became central sites for the articulation of ideological differences in the modern public sphere. ${ }^{5}$ Just as the politicization of key categories, such as "freedom," "nation," or "republic," registered the bifurcation of the political arena in the first third of the nineteenth century, the varied meanings given to Jenseits corresponded to the growing bifurcation of religious opinion into liberal and orthodox camps. Jenseits was, however, hardly a neutral term in this struggle, particularly after a substantive shift in its usage occurred in the late 1840s. It became a choice word in the arsenal of those who sought to disprove the existence of an afterlife and to secularize German public life. For the next century, a broad anticlerical movement continually invoked the categorical

Spacing Concepts, trans. Todd Presner, Kerstin Behnke, and Jobst Welge (Stanford, Calif.: Stanford University Press, 2002). For an interpretation of Koselleck's method, see Kari Palonen, "The History of Concepts as a Style of Political Theorizing. Quentin Skinner's and Reinhart Koselleck's Subversion of Normative Political Theory," European Journal of Political Theory 1:1 (July 2002): 96-111.

${ }^{4}$ On the secularization of Christian concepts of the afterlife, see Colleen McDannell and Bernhard Lang, Heaven: A History, 2nd ed. (New Haven, Conn.: Yale University Press, 2001). The appearance and popularization of "Jenseits" also corresponded to the grand realignment of assumptions about the human relationship "to nature and to history, to the world and to time" that Koselleck found manifested in the conceptual changes that took place between the mideighteenth and the mid-nineteenth century, that is, at the inception of the modern era: Koselleck, "Einleitung," xv.

${ }^{5}$ Koselleck, "Einleitung," xvi-xviii. 
pair Jenseits/Diesseits (the Beyond/the here-and-now) in its efforts to destabilize the foundational beliefs of the monotheistic religions of Germany. Jenseits came to symbolize the absence of heaven. The currency enjoyed by this use of Jenseits rose in the 1840s and fell after the Second World War, making it a marker of the age in which secularism played a key role in religious and political conflict. ${ }^{6}$ Today, the term has become neutralized, a point we shall return to at the end of this essay.

Secularists were so successful in defining "the Beyond" in the liberal public sphere that their definition could already serve as the central pun in a caricature that appeared in the popular Berlin satirical journal Kladderadatsch to commemorate the completion of the first transatlantic telegraph line in 1869 (see fig. 1). In this image, American liberty bursts from the heavens with a luminous telegraph cable that sheds light on the dark figures of European political life scurrying around below. Blind to the industrial power represented by the unity of republicanism and the free and instantaneous exchange of information, the Europeans leaders-among them Napoleon III and Otto von Bismarck - are trying to catch light with sieves. The caption announces that a "cable" has arrived from "a better Beyond." The term carries a double irony. Manifestly invoking the geographical location of America beyond the ocean, it figuratively suggests that science and republican government had emptied out heaven there and would soon weed religious obscurantism out of European public life as well.

How did the Beyond come to be hollowed out in mid-nineteenth-century Germany? In seeking an answer to this question, it will be necessary to challenge some common assumptions that developed in the nineteenth century and still dominate much contemporary writing on secularization and secularism. In critiquing these assumptions, it is hoped that this essay can contribute to a more subtle understanding of some of the forces at work in the emergence of what philosopher Charles Taylor has recently called the "secular age."

The first assumption is implicit in the caricature just described, namely that science and technology — seen as two key agents of secularization-naturally supported secularism. Contrary to this view, this essay will show that although all of the definitions of the Beyond that emerged in the 1830s and 1840 s responded in some way to the secularizing effects of scientific

\footnotetext{
${ }^{6}$ The polemical aura thus acquired by the term "Jenseits" will not have been lost on two Germanspeaking atheists, Friedrich Nietzsche and Sigmund Freud, who employed it-albeit as a preposition - in the titles of two of their most famous tracts. Friedrich Nietzsche first published Jenseits von Gut und Böse (Beyond Good and Evil) in 1886. Sigmund Freud's Jenseits des Lustprinzips (Beyond the Pleasure Principle) appeared in 1920.

${ }^{7}$ Charles Taylor, A Secular Age (Cambridge, Mass.: Harvard University Press, 2007).
} 


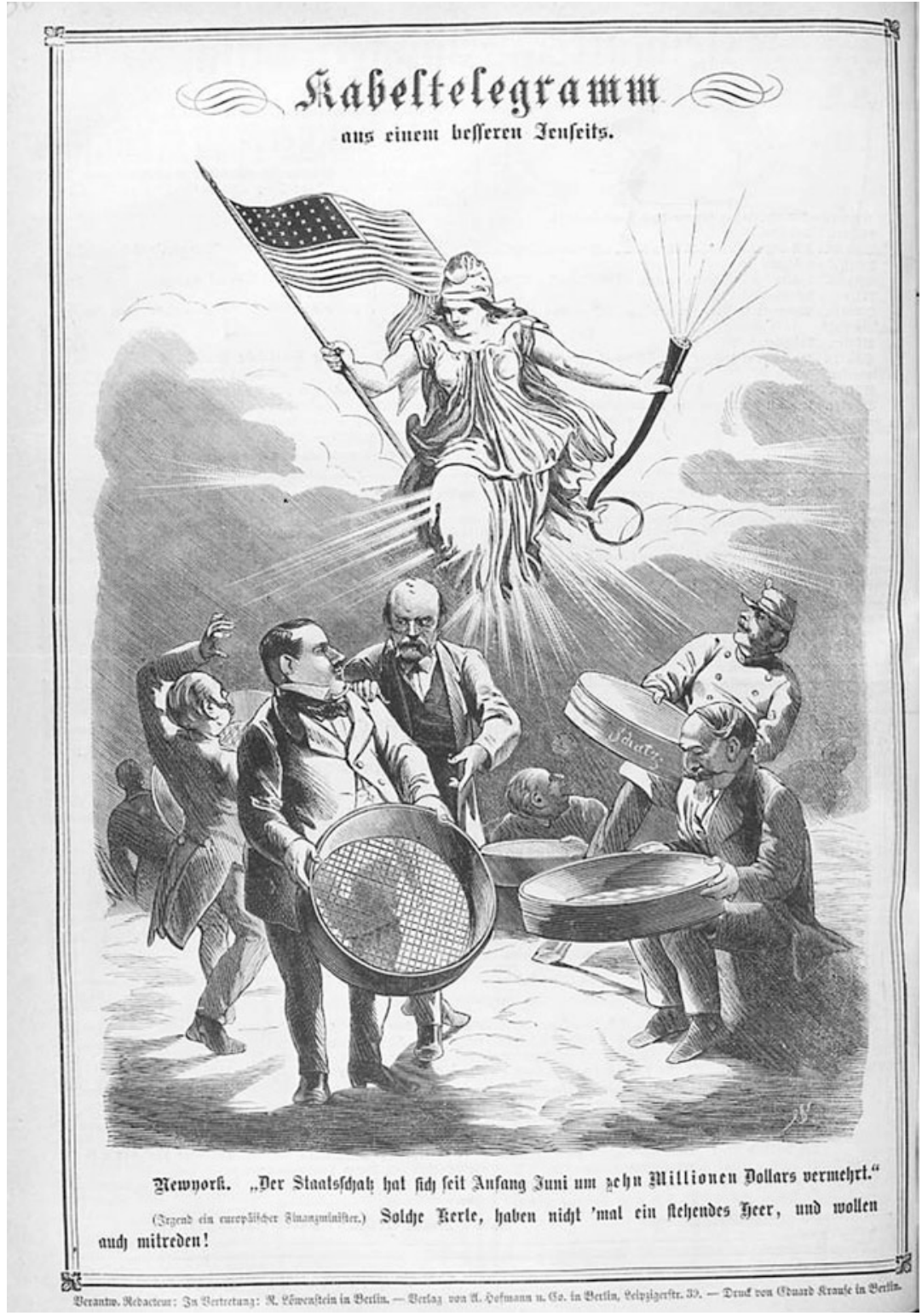

Fig. 1. "Cable telegram from a better Beyond" Kladderadatsch, 32-29-30 (27 June 1869): 120. The caption beneath reads: "New York. 'The treasury has grown by more than ten million dollars since the beginning of June.' (Some European Finance Minister [says of the Americans,]) 'Such fellows don't even have a standing army and want to speak up anyway."' Image courtesy of the Staatsbibliothek zu Berlin. 
empiricism, only some developed in a pointedly secularist direction and denied the existence of a life after death.

In order to explain the growing polemical usage of the Beyond after 1845, one must look beyond scientific innovation to the dynamics of secularism. Here it is necessary to confront a second, contrary assumption about secularism, one developed early on by defenders of religion. They held that secularists were chiefly motivated by their politics. It is true that secularism was always a key element of modern partisan politics, particularly on the radical left. However, even among early German communists, whose Soviet counterparts undertook the most significant antireligious violence in history, religious motivations were rarely absent. ${ }^{8}$ Just before the end of the First World War, for example, two of Berlin's leading radical socialists published a Free People's Catechism, which told parents that if they brought their children to abandon "the search for their salvation in an unknown Beyond (Jenseits), ... a life-affirming, powerful enthusiasm for nature and noble humanity will sprout within them, and [awaken] the will to become productive and free people." Hoffmann, became key figures in the German Revolution of 1918/20 and spearheaded the fusion of the left wing of their Independent Social Democratic Party (USPD) with the smaller Communist Party in $1920 .{ }^{10}$ Däumig and Hoffmann were, at the same time, leading figures in the Berlin Free Religious Congregation. Many of the most prominent radicals of the revolution of 1848 were also Free Religious, including Gustav von Struve, the co-leader of the armed "Baden Rebellion," and Robert Blum, whose execution after the failed Vienna uprising in November 1848 made him the revolution's most important martyr. ${ }^{11}$

\footnotetext{
${ }^{8}$ During the late 1920 s, the infallibility of "scientific materialism" became firmly ensconced in the growing Stalinist orthodoxy while, at the same time, many churches, synagogues, and mosques were torn down, converted into cinemas, or turned into "antireligious museums": Daniel Peris, Storming the Heavens: the Soviet League of the Militant Godless (Ithaca, N.Y.: Cornell University Press, 1998).

${ }^{9}$ Ernst Däumig, Freier Volkskatechismus: Ein Wegweiser zur echten Nächstenliebe und freien Menschenwürde (Berlin: A. Hoffmann, n.d. [1918]), 5.

${ }^{10}$ Däumig became co-chairman of the Independent Social Democratic Party (USPD) in 1919 and was elected to the same post in the United Communist Party in 1920. The brief tenure of the booklet's publisher and anticlerical firebrand Adolph Hoffmann as Prussian co-minister of education remained an enduring trauma for the state churches, who forever associated his name with the "godless" revolution. On Däumig, see David Morgan, "Ernst Däumig and the German Revolution of 1918," Central European History 25:4 (1982): 801-813.

${ }^{11}$ After the suppression of the Revolution of 1848, many of the Free Religious preachers and activists were forced into exile in the United States and Britain. Particularly in the former, they established a far-flung network of Free Religious Congregations within the German-speaking community: Katja Rampelmann, Im Licht der Vernunft: Die Geschichte des deutschamerikanischen Freidenker-Almanachs von 1878-1901 (Wiesbaden: Franz Steiner, 2003).
} 
Free Religion was the most important seedbed of Germany's organized secularist movements. It began among the dissident Catholics and Protestants, whose rationalist theology and political radicalism had led them to break off from or be expelled by their churches in the mid-1840s. When these dissidents joined together in the Union of Free Religious Congregations in 1859, their leaders could not agree to call the new organization Christian. In fact, many had already come to embrace pantheistic and even atheistic positions. Out of this organizational matrix emerged the German Freethought League (1881) and the German Monist League (1906). ${ }^{12}$ Despite their social and philosophical heterogeneity, these organizations - known by the moniker "freigeistig" (freespiritual/freethinking) — were united by vigorous anticlericalism, adherence to a natural scientific worldview, and the negative critique of the Beyond. Most freigeistig organizations were banned, and some were co-opted by the National Socialist regime in $1933 / 34 .{ }^{13}$ After 1945 , the freigeistig movement and the Beyond failed to recapture their former positions in German political and religious conflict.

The following conceptual history of the Beyond draws on the early history of Free Religion to bring into sharper relief the structures of dissent that were hollowing out heaven and driving the emergence of secularism in the second

\footnotetext{
${ }^{12}$ Most of the literature on Freigeistigkeit has focused on the first five years of Free Religion: Hans Rosenberg, "Theologischer Rationalismus und vormärzlicher Vulgärliberalismus," in Hans Rosenberg, Politische Denkströmungen im deutschen Vormärz (Göttingen: 1972 [1930]); Jörn Brederlow, "Lichtfreunde" und "Freie Gemeinden": Religiöser Protest und Freiheitsbewegung im Vormärz und in der Revolution von 1848-49 (Munich, Vienna: Oldenbourg, 1976); Friedrich Wilhelm Graf, Die Politisierung des religiösen Bewußtseins. Die bürgerlichen Religionsparteien im deutschen Vormärz: Das Beispiel des Deutschkatholizismus (Stuttgart: Frommann-Holzboog, 1978); Sylvia Paletschek, Frauen und Dissens: Frauen im Deutschkatholizismus und in den freien Gemeinden 1841-1852 (Göttingen: Vandenhoeck \& Ruprecht, 1990); Andreas Holzem, Kirchenreform und Sektenstiftung. Deutschkatholiken, Reformkatholiken und Ultramontane am Oberrhein (1844-1856) (Paderborn: Schöningh, 1994); Dagmar Herzog, Intimacy and Exclusion: Religious Politics in Pre-Revolutionary Baden (Princeton, N.J.: Princeton University Press, 1996). On the history of the freigeistig movement between 1890 and 1914, see Horst Groschopp, Dissidenten. Freidenkerei und Kultur in Deutschland (Berlin: Dietz, 1997); Frank Simon-Ritz, Die Organisation einer Weltanschauung: die freigeistige Bewegung im Wilhelminischen Deutschland (Gütersloh: Kaiser, 1997).

${ }^{13}$ Initial research into the fate of Freigeistigkeit under National Socialism can be found in: Ulrich Nanko, Die Deutsche Glaubensbewegung. Eine historische und soziologische Untersuchung (Marburg: Diagonal, 1993); Ulrich Nanko, "Das Spektrum völkisch-religiöser Organisationen von der Jahrhundertwende bis ins 'Dritte Reich'," and Matthias Pilger-Strohl, "Eine deutsche Religion? Die freireligiöse Bewegung-Aspekte ihrer Beziehung zum völkischen Milieu," in Völkische Religion und Krisen der Moderne: Entwürfe "arteigener" Glaubenssysteme seit der Jahrhundetwende, ed. Stefanie v. Schnurbein and Justus Ulbricht (Würzburg: Königshausen \& Neumann, 2001), 208-226, 342-366. For two contrasting views of the interaction of paganism and Protestantism under National Socialism, see Richard Steigmann-Gall, The Holy Reich: Nazi Conceptions of Christianity, 1919-1945 (Cambridge: Cambridge University Press, 2003) and Karla Poewe, New Religions and the Nazis (New York: Routledge, 2006).
} 
third of the nineteenth century. This secularism, it is argued, was related to yet distinct from secularization. Furthermore, despite its political overtones, secularism did not emerge outside religion. The religious and political motives at work in secularist dissent were always intertwined.

To substantiate these claims, the essay proceeds in four steps. First it examines the emergence of the term "the Beyond" within the gradual secularization of Christian concepts of the afterlife that took place between the Enlightenment and the mid-nineteenth century. The second section demonstrates that natural scientific empiricism alone did not empty out the hereafter. In the 1830 s and 1840 s there existed several competing definitions of the Beyond that all conformed to a natural scientific paradigm and yet contained contrary conclusions about the existence of a life after death. As the third section shows, the polemical elimination of the Beyond only emerged after popular natural science became articulated within structures of dissent. Here, the essay turns to the history of early Free Religion, in which arguments for the non-existence of the Beyond were tied to the ongoing separation from and struggle with the state churches. These structures of dissent account for the longevity of criticism of the Beyond for many decades past the point at which Freigeister believed they had dispensed with all Christian metaphysics. Ultimately, as the fourth section reveals, this criticism was essential to the construction of the freigeistig worldview. The so-called "religions of Diesseits," that is, natural scientific monism and atheistic humanism, could only sustain themselves through the ongoing invocation and rhetorical elimination of Jenseits.

\section{The Beyond and the Secularization of the Afterlife: From the ENLIGHTENMENT TO THE 1830s}

Like its English, French, and Italian equivalents, the noun "Jenseits" was derived from the prepositional adverb of expressions such as "jenseits des Grabes" ("beyond the grave"). Whereas this sort of prepositional use of "beyond" in reference to the afterlife had been common among writers across Europe since the Reformation, the abstract noun appears to have entered into German first, where it was employed already in the 1780 s. $^{14}$ Usage of the "Beyond" in English and "l'au-delà" in French followed in the nineteenth century. ${ }^{15}$

\footnotetext{
${ }^{14}$ Already in the sixteenth century, Montaigne used the phrase "au delà cette vie": Dictionnaire de la Langue Française du seizieme Siècle (Paris: Libraire Ancienne Honoré Champion, 1932), vol. 10, 766.

${ }^{15}$ A German-English dictionary of 1828 translated "das Jenseits" not as "the Beyond" but as "the other world." The date of the earliest citation of "the Beyond" found in the Oxford English
} 
Dictionary entries record a term's popularization after the fact. A more accurate measure of the point at which "the Beyond" became a central term of popular debate in Germany can be taken from its appearance in book titles. This method reveals 1832 as a rough turning point. Whereas titles published before this date used jenseits as a preposition, primarily to describe the geographic relations of two territories, 1832 showed a marked increase in the number of titles using Jenseits as a noun to designate the afterlife.

This early history of the Beyond, between its appearance in German literature in the $1780 \mathrm{~s}$ and its advancement to a familiar popular category in about 1832, corresponds to the period in which new Enlightenment conceptions of the afterlife were becoming widely popularized in Germany. In their wide-ranging study Heaven: A History, Colleen McDannell and Bernhard Lang argued that during the Enlightenment the theocratic heaven of the Reformation began to give way to more anthropocentric visions. The authors illustrated this development through a case study of the influential mystical work Heaven and Hell (1752) by Emanuel Swedenborg. The Swedish visionary described heaven as a place for the continuation and further development of the individual's personal relationships and his or her projects of self-improvement. In the mid-nineteenth century, such views became widespread, particularly among Protestants, who now saw heaven less as an "eternal Sabbath" and more as a "heavenly home" where the departed enjoyed "an idealized life of leisure, service and spiritual growth." 16 The notion that heaven extended and improved on what Christians had experienced in this world, rather than transporting them to a completely other place — a garden or New Jerusalem — may be considered a secularization of the afterlife, if that term is understood to mean an intrusion of secular institutions or ideas into the religious sphere. ${ }^{17}$

Dictionary is 1835. "L'au-delà" achieved wide circulation in France in the 1830 s but was first accepted as a noun in a French dictionary in 1866. Italians evidently picked up on the term even later, most likely from the French. "L'aldilà" did not appear in an Italian dictionary until 1908: Complete Practical Grammar of the German Language, 4th ed. (Leipzig and London: J. C. Hinrichs, 1828), 386; A New English Dictionary on Historical Principles (Oxford: Clarendon, 1888) I:841-842; Trésor de la Langue Française (Paris: Centre National de la Recherche Scientifique, 1978), 1012; Dizionario etimologico della lingua italiana (Bologna: Zanichelli, 1979), $1: 36$.

${ }^{16}$ McDannell and Lang, Heaven: A History. On Swedenborg, see 181-227, n. 356. See also Bernhard Lang, Himmel und Hölle: Jenseitsglaube von der Antike bis heute (Munich: Beck, 2003). Two more recent histories of heaven that focus on ancient and medieval conceptions are Jeffrey Burton Russell, A History of Heaven: The Singing Silence (Princeton, N.J.: Princeton University Press, 1997); and Alister McGrath, A Brief History of Heaven (Malden, Mass.: Blackwell, 2003).

${ }^{17}$ See the indispensible conceptual history of the term "secularization" by Hermann Lübbe, Säkularisierung. Geschichte eines ideenpolitischen Begriffs, 2nd ed. (Munich: Karl Alber, 1975). 
In his recent study of Enlightenment German Protestant theology, the church historian Walter Sparn has taken a more Weberian stance on the secularization of heaven as a "disenchantment." In addition to seeing the afterlife as a place for the further development of the human personality, Enlightenment theologians increasingly "metaphorized" heaven, he argues. They ceased to concentrate on the location and qualities of heaven and began to question the physical existence of hell. Heaven's transformation into an abstract metaphor was reflected in church painting, where baroque angels and demons were replaced by "non-iconic symbols like the eye in the triangle." 18

For the philosopher Georg Wilhelm Friedrich Hegel, the end result of this metaphorization of the transcendent was in fact emptiness. Having lost its content to the world, the truth of faith had become "an empty beyond (Jenseits), for which a fitting content can no longer be found." ${ }^{19}$ Hegel believed that his generation was the first to recognize that the centuries of theological thought and faith directed at an otherworldly transcendent were, in fact, a "treasure ... squandered on heaven." 20 This recognition was the source of modern religious alienation, yet for Hegel it was also a crucial step in his dialectic of the Spirit, through which the ethical world that "is rent asunder into this world and a beyond (Diesseits und Jenseits) ... return[s] into the simple self-consciousness of the Spirit." ${ }^{21}$ Hegel brought the term "Jenseits" into philosophical vocabulary because of its ability to express what he saw as the growing metaphorical emptiness of the religious transcendent. $^{22}$

Most writers of Hegel's era, however, invoked "the Beyond" to express anxiety and uncertainty about what was to follow death. One of the earliest instances is found in Friedrich Schiller's play The Robbers (1781) at the moment the proto-revolutionary outlaw Karl Moor contemplates suicide:

Hartmut Lehmann has also argued against the expectation established by modernization theorists that disenchantment is a historically inevitable correlate of industrialization and democratization. Instead, Lehmann, like many historians, has come to see secularization as one aspect of the reconfigurations of religion in modernity: see Hartmut Lehmann, ed., Säkularisierung, Dechristianisierung, Rechristianisierung im neuzeitlichen Europa: Bilanz und Perspektiven der Forschung (Göttingen: Vandenhoeck \& Ruprecht, 1997) and Hartmut Lehmann, Säkularisierung: Der europäische Sonderweg in Sachen Religion (Göttingen: Wallstein, 2004).

${ }^{18}$ Walter Sparn, "Aussichten in die Ewigkeit' Jenseitsvorstellungen in der neuzeitlichen protestantischen Theologie," in Jenseits, ed. Hölscher, 12-39, n. 28, 29.

${ }^{19}$ G. W. F. Hegel, Phenomenology of Spirit, trans. A. V. Miller (Oxford: Clarendon, 1977), 63.

${ }^{20}$ G. W. F. Hegel, On Christianity: Early Theological Writings, trans. T. Knox (Philadelphia: University of Pennsylvania Press, 1983), 159.

${ }^{21}$ G. W. F. Hegel, Phenomenology, 265.

${ }^{22}$ A convincing argument for the centrality of the term "Jenseits" to Hegel's religious philosophy is made by the Bochum theologian Christian Link, "Das 'leere Jenseits': Hegels Analyse der neuzeitlichen Religion," in Jenseits, ed. Hölscher, 63-79. 
Be what you will, you nameless Beyond-as long as this self of mine stays true to me ... Be what you will, as long as I can take my Self with me. Externals are only the varnish on a man: I am my own Heaven and Hell. ${ }^{23}$

By the 1830s, the authors who chose "the Beyond" for book titles were no doubt tapping into a more widespread anxiety about the afterlife. The Great Beyond, Now Demonstrably Certain (1832) and works promising their readers "A Glimpse into the Beyond" speak to the problem of locality and the need to affirm the physical existence of heaven. ${ }^{24}$

Although some German Protestant and Catholic theologians took up the term in the 1830 s, ecclesiastical use of "the Beyond" did not become widespread until the $1860 \mathrm{~s}^{25}$ Those churchmen who did employ the term often did so apologetically, responding directly or indirectly to prior speculation by writers who were most often not writing at a church's behest. A similar pattern was found in the English-speaking world, where "the Beyond" was popularized in critical and speculative texts of the $1840 \mathrm{~s}^{26}$ When the Presbyterian minister

${ }^{23}$ The Robbers, act IV, scene 5, in Schiller: Five Plays, trans. Robert David MacDonald (London: Oberon, 1998), 67-189, n. 163.

${ }^{24}$ Ludwig Hofacker, Das grosse Jenseits: nun erschaulich gewiß; eine freudige Botschaft (Tübingen: Verlag der Buchhandlung zu Guttenberg, 1832). Arthur vom Nordstern (pseud. for Gottlob Adolf Ernst von Nostizt und Jänckendorf), Blicke der Vernunft in das Jenseits (Dresden: Gärtner'schen Buchdrückerei, 1833). Another "glimpse into the Beyond" was offered by a Protestant minister who encouraged parents and educators to help young people overcome life's despairs by looking into the afterlife to show that the material world was but a passing one: C. A. Stange, Ein Blick in das Jenseits (Berlin: Plahn'schen, 1836).

${ }^{25}$ Bernhard Lang notes that, although the terms "Jenseits" and "Diesseits" appear in the System der katholischen Dogmatik by the neoscholastic theologian Heinrich Klee in 1831, they were not commonly used by Catholic theologians until the 1860s. Lang, "Die zweigeteilte Welt: 'Jenseits' und 'Diesseits' in der katholischen Theologie des 19. und 20. Jahrhunderts," in Jenseits, ed. Hölscher, 203-232, n. 210. There is also evidence that the terms were entering Protestant theology in the early 1830s. When he revised his Commentar über die Schriften des Evangelisten Johannes (Bonn: Eduard Weber, 1833), 324, Friedrich Lücke, the well-known professor of Protestant theology and friend of Friedrich Schleiermacher, added mention of "Diesseits" and "Jenseits" in reference to contemporary "dialectical criticism." According to Sparn, Schleiermacher himself apparently refrained from using the term "Jenseits," even in the 1831 revision of his Glaubenslehre: Sparn, Aussichten, $36-37$.

${ }^{26}$ A particularly vivid example of the speculative use of the term "the Beyond" is found in an essay of 1847 written by the American lawyer Richard B. Kimball, who had immersed himself in Spinozist and idealist philosophy during a lengthy stay in Germany in the 1830s:

No, I was not happy. ... For faith had never been by me sufficiently cherished; and without this great connecting link between two worlds, what wonder that difficulties were presented which I could not overcome? ... The idea of Death! This now constantly obtruded itself before my mind. [I knew] [t] hat death would close all my earthly relations. The Beyond - the Beyond! What had it to do with me? So long as I kept my hold on life, my philosophy bore me along smoothly enough. I was a king, a monarch; all were monarchs. But ... when the thought forced itself upon my mind, that I should ... lose my individuality, my identity-my very 
Thomas Hamilton later chose the term for the title of a popular theological work Beyond the Stars, his apologetic aim became clear in the first chapter: "A Settling of Localities." Hamilton sought to dismiss recent works that described heaven as a state of non-corporeal being rather than as a place. This view dissolved heaven "not into the airy, unsubstantial, transcendental thing which they speak of, but into an airy, unsubstantial nothing,- - mirage, a dream." 27

Yet even this reaffirmation of traditional notions of Christian heaven from the otherwise respectable author of a history of Irish Presbyterianism and president of Queen's College in Belfast did not escape the theological speculation associated with invocations of the Beyond. Citing an unnamed astronomical source that had declared the star Alcyone in the Pleiades constellation "to be the central sun about which the universe of stars comprising our whole astral system revolves," Hamilton conjectured that science might have located the "seat of heaven." Might not Alcyone, he concludes, be the "definite locality called heaven," the "grand central metropolis of the universe"? ${ }^{28}$

\section{Three Definitions of the Beyond in an Age of Science}

Hamilton's speculative cosmology raises the question of the role of natural science in the secularization of the Beyond. According to Walter Sparn, the "cosmological evacuation of the ... Beyond" resulted from the "mechanization of the world picture" (E. J. Dijksterhuis) that began with early modern science. ${ }^{29}$ Speaking for this explanation is the significant advance of mechanistic thought in Germany in the 1830 s and 1840 s, when a new generation of natural scientists sought to excise metaphysics from science through a physiological reductionism that permitted only physical, experimentally verifiable evidence in scientific explanation. German empiricism took on elements of a creed similar to Auguste Comte's positivism and became inextricably linked to the term "worldview" (Weltanschauung) that was popularized at that time. ${ }^{30}$ Worldview

Me, Myself - great God! What absolute horror would seize upon me; what terrific apprehensions hung like clouds around my heart!

This citation demonstrates how the two dimensions of secularization discussed above came to clash in the nineteenth century. On the one hand, the author expected there to be an extension of personal identity into the afterlife while, on the other, he was anxious that such an extension might not occur: Richard B. Kimball, "Saint Leger Papers: Second Part," in The Knickerbocker XXIX (1847): $68-75$, n. 68 .

${ }^{27}$ Thomas Hamilton, Beyond the Stars; or, Heaven, its Inhabitants, Occupations and Life, 4th ed. (Edinburgh: T. \& T. Clark, 1896 [1888]), 24.

${ }^{28}$ Ibid., 41 .

${ }^{29}$ Sparn, Aussichten, 21, 28

${ }^{30}$ In 1845, Emil Du Bois-Reymond wrote of fellow physiologist Hermann Helmholtz that he stood "entirely on our vantage point with respect to world view": cited in David Galaty, "The 
implied the will to see all matter from a single perspective and within a single system. This posed a problem for Christianity, for, in the emerging consciousness that space was saturated, heaven-like angels, God, and the devil — came into an ontological predicament.

However, although it may be conceded that "the Beyond" marked the point of friction between the emerging project of a "unified, natural-scientific worldview" and the concept of Christian transcendence, few authors writing before 1845 considered the liquidation of the Beyond to be a foregone conclusion. Early texts on the Beyond reveal at least two different strategies for solving the problem of space and afterlife without contradicting natural science. The first was offered by Christian rationalism and the second by spiritualism.

In 1833 a high-ranking state minister in Saxony, who simultaneously held top posts in the country's Protestant church and its Masonic lodge, published an epic poem titled Reason's Glimpses into the Beyond. ${ }^{31}$ The poem opens with the figure of a pilgrim seeking an oasis. This is a dual metaphor for the soul's journey to heaven and the quest for knowledge. Both are uncertain undertakings, but the poet concludes with the rationalist conviction that reason and faith lead to the same end:

\section{Here too burns iridescent \\ Faith and Reason as one. \\ That which Reason proclaims \\ Perceives God's kingdom. \\ Though secrets remain unillumined \\ Even for the most intrepid scout; \\ Yet here the good man stands \\ Already closer to the spirit-world.}

In good Masonic fashion, the poet here employs mystery to achieve unity. The Beyond itself is the obscure point at which the rationalist synthesis of reason and faith takes place.

In the 1840 s and 1850 s a second approach to harmonizing natural science with an affirmative understanding of the Beyond emerged in books with titles such as Voices from the Beyond, or The Secrets of the Beyond: Revelations about Life after Death. These works purported to explain the material manifestations of

Philosophical Basis of Mid-Nineteenth Century German Reductionism," Journal of the History of Medicine 29:3 (July 1974): 295-316, n. 300.

${ }^{31}$ Nordstern (pseud.), Blicke der Vernunft in das Jenseits. The author Gottlob Adolf Ernst von Nostizt und Jänckendorf (1764-1836) was Royal Saxon Konferenzminister, OberkonsistorialratPräsident and Landesgroßmeister of the Saxon Masonic lodges. His other works include Sinnbilder der Christen (1818), Liederkreis für Freimaurer, (2 vols., 1815), and Anregungen für das Herz und das Leben (1825). 
dead spirits in this life. Looking for and finding the Jenseits in Diesseits was the central activity of the spiritualist movement, whose popularity in Europe grew dramatically in 1853 after spectacular reports from the United States of "tableknocking" by dead spirits summoned by a medium. The literature on spiritualism has shown that, although the movement was fiercely opposed to materialism, it was not antiscientific. Many leading spiritualists understood theirs as an eminently rational enterprise. ${ }^{32}$

German spiritualism received scientific support from the physiologist Gustav Fechner who, in addition to his foundational scientific work, published his thoughts on death and the Beyond in two treatises, The Little Book of Life after Death (1836) and Zend-Avesta or Over the Things of Heaven and of the Beyond: From the Viewpoint of the Observation of Nature (1853). ${ }^{33}$ In these works, Fechner elaborated a theory of death as one point of transition in the three-stage development (Bildung) of the spirit. The first phase commences with conception, when the soul begins to organize itself physically as an embryo. Then, after birth, the human soul uses its physical senses to establish a conscious relationship to itself and the world. Upon death, this spirit enters a third and final stage of development. It leaves the isolation of the individual body and, "no longer chained by it, will now flow into nature with complete freedom. It will no longer just perceive light and sound waves, as these beat against its eye and ear, but instead [the spirit] will itself roll forth like them through the sea of ether and air." The spirit will "no longer wander outwardly through forest and meadow green, but rather feelingly (fühlend) penetrate forest and meadow and the people

\footnotetext{
${ }^{32}$ In the popular scientific spirit of the day, a recent German convert to spiritualism urged his readers to undertake their own "experiments" with table-knocking and assemble a group of skeptical "non-believers" to a séance, where they could make empirical observations: Bernhard Otto, Die Sprache der Verstorbenen oder das Geisterklopfen: Stimmen aus dem Jenseits und enthüllte Geheimnisse des Grabes. Ein unumstößlicher Beweis für die Fortdauer der Seele nach dem Tode und deren Weidervereinigung mit ihren Lieben. Nach gesammelten authentischen Thatsachen dargestellt, 3rd expanded ed. (Leipzig: Gustav Pönike, n.d. [1855]). See also the scientistic "magnetic-ecstatic method" for communicating with the dead found in Louis Alphonse Cahagnet, Die Geheimnisse des Jenseits: oder, die Fortdauer nach dem Tode und die Berufung und Befragung des Vorstorbenen auf magnetisch-ekstatischem Wege (VerlagsComptoir, 1851). On the scientific claims of spiritualists, see Ann Braude, Radical Spirits: Spiritualism and Women's Rights in Nineteenth-Century America (Boston: Beacon, 1989); Janet Oppenheimer, The Other World: Spiritualism and Psychical Research in England, 1850-1914 (Cambridge: Cambridge University Press, 1985); Diethard Sawicki, Leben mit den Toten: Geisterglauben und die Entstehung des Spiritismus in Deutschland 1770-1900 (Paderborn: Schöningh, 2002).

${ }^{33}$ Gustav Fechner, Das Büchlein vom Leben nach dem Tode, 3rd ed. (Hamburg and Leipzig: Leopold Voss, 1887 (1836)); Gustav Fechner, Zend-Avesta oder über die Dinge des Himmels und des Jenseits: Vom Standpunkt der Naturbetrachtung, vol. I (Über die Dinge des Himmels) (Leipzig: Leopold Voss, 1854). The Büchlein had numerous English editions, including The Little Book of Life after Death, trans. M. Wadsworth (Boston: Little, Brown \& Co. 1904).
} 
wandering therein." ${ }^{34}$ Jenseits exists here as another dimension of Diesseits and, as such, the dead remain an integral part of living nature.

In Zend-Avesta, Fechner claimed that unlike idealistic natural philosophy, which "[descends from the] general soul to the individual," his method worked inductively from empirical observations. His pantheistic teachings were, he felt, "without internal contradiction" and "connected to the facts, laws and demands of our contemporary life, and even find positive support there." Nonetheless, he cautioned that they had to remain merely "reasonable possibilities" because, according to Fechner, the Beyond could not be accessed by the empirical method alone: "whoever wants to find a way beyond this life (das Diesseits) cannot merely direct his gaze at that which lies before his feet."35

Despite such caveats, Fechner sought to offer his readers some scientific proof that the spirits of the dead "fill and penetrate" nature. His Little Book of Life after Death presented rare cases "in this current life," in which one sees "consciousness wander out of the narrow body ... and then return again to bring news of that which occurs in a distant place or ... in a distant time; for the length of the future rests on the width of the present." Citing reports from survivors of drowning or of drug-induced narcosis, Fechner characterized the experience of near-death as follows: "suddenly a crack opens in the otherwise always sealed door between this and that world (Diesseits und Jenseits) only to quickly close again." This door would first "open entirely upon death ... never to close again.."36

Whether through Fechner's esoteric natural philosophy, through popular accounts of visits from the reawakened dead, ${ }^{37}$ or through rituals of "tableknocking," spiritualists in the 1840s and 1850s believed they had discovered various means of opening the crack in the door between this life and the next. Tarrying at this doorstep, venturing from one side to the other and back again, remained the essence of spiritualism. It received symbolic expression at the end of the century with the book title At the Beyond ("Am Jenseits"). Germany's most famous writer of Western novels, Karl May, chose it for his first foray into spiritualist literature in 1899. Sascha Schneider's cover illustration for the 1906 edition (fig. 2) shows the blind Arab seer El

\footnotetext{
${ }^{34}$ Fechner, Das Büchlein, 48. McDannell and Lang aptly call spiritualism a "thick description of heaven": Heaven: A History, 292-303.

${ }^{35}$ Fechner, Zend-Avesta III, iv, v.

${ }^{36}$ Fechner, Das Büchlein vom Leben nach dem Tode, 7, 66-67.

${ }^{37}$ The narrator in an 1842 book, Voices from the Beyond, describes his encounter with a mysterious stranger, who leaves him with a packet of letters describing his experiences as a man who had risen from the dead. F. Nork (pseudonym for Seligmann Kohn), Stimmen aus dem Jenseits: Oder das Todtengericht im Grabe; den mündlichen Mittheilungen eines weidererwachten Scheintodten getreu nacherzählt (Weimar: Bernhard Friedrich Voigt, 1842). Other apparently spiritualist titles by Kohn (1803-1850) were Die Existenz der Geister (1841), Zeriels Reise auf der Oberwelt (1830), and Der Mystagog (1850).
} 


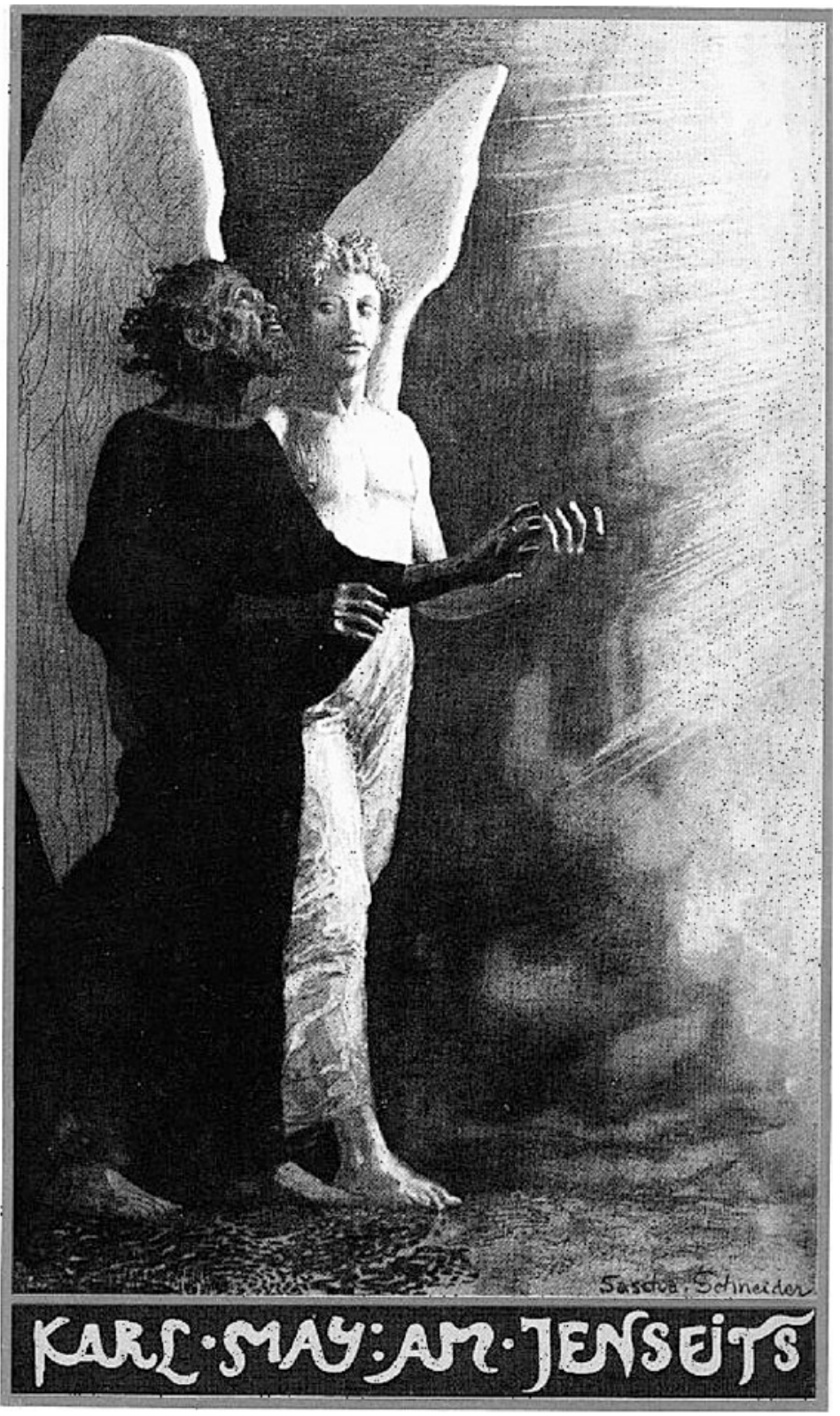

Fig. 2. Sascha Schneider, An der Pforte des Jenseits (1905). Title page illustration to the 1906 edition of Karl May's spiritualist novel At the Beyond. Scanned image courtesy of Wolfgang Hermesheimer, Karl May Gesellschaft, Germany. 
Mündeschi in a somnambulistic trance. He has left his body and is being guided by an angel to an intermediate plane, from which he will gaze into the Beyond. ${ }^{38}$

A third meaning given to the Beyond in the 1830 s and 1840 s can be identified with the emergence of a secularist philosophy. A key figure here is the left Hegelian Ludwig Feuerbach, who offers a contemporary contrast to Fechner. Whereas Fechner reached from natural science to theology, Feuerbach came from theology and philosophy to natural science. Like Fechner, Feuerbach also addressed two theoretical texts to the problem of immortality. ${ }^{39}$ Feuerbach's career as a university theologian found an abrupt and premature end when his authorship of the pseudonymously published Thoughts on Death of 1830 was revealed. His essential position on the Beyond, namely that it did not exist, remained unchanged when he returned to the subject in his 1846 work The Question of Immortality from the Viewpoint of Anthropology. What had changed in the intervening sixteen years was his use of the term. "The Beyond" appeared only infrequently in the earlier text, which offered a psychological explanation of the belief in immortality as a product of projection and compensation. In 1846 he invoked "the Beyond" frequently and entirely negatively.

"Anthropology" was the term that Feuerbach proposed for his new spiritual humanism in the seminal work The Essence of Christianity (1841). But, whereas in 1841 he saw anthropology as a further development of human religion and consciousness through Christianity, the 1846 text described Christianity, and particularly the belief in the Beyond, as a hindrance to anthropology. Between 1841 and 1846 Feuerbach's critique of the Beyond had thus moved from psychological and religious-historical explanations to sociological and political ones. No longer merely a form of self-deception, Feuerbach came to see the belief in immortality in the Beyond as a tool of social deception. ${ }^{40}$

Thus, on the eve of the Revolution of 1848, Feuerbach's humanism had come to require the liquidation of the Beyond and the abandonment of Christianity:

\footnotetext{
${ }^{38}$ Karl May, Am Jenseits: Reiseerlebnisse von Karl May, 3rd ed., with a cover illustration by Sascha Schneider (Freiberg i. Br.: Friedrich Ernst Fehsenfeld, n.d. [1906]). See the discussion of this work in Diethard Sawicki, “'Alpenglühen im Himmelreich': Das Jenseits Karl Mays,” in Jenseits, ed. Hölscher, 123-137.

${ }^{39}$ Ludwig Feuerbach, "Todesgedanken," in Sämmtliche Werke (Stuttgart: Fr. Frommans, 1903 [1830]) with an English translation by James Massey, Thoughts on Death and Immortality (Berkeley: University of California Press, 1980). Ludwig Feuerbach, "Die Unsterblichkeitsfrage vom Standpunkt der Anthropologie," in Sämmtliche Werke (Stuttgart: Fr. Frommans, 1903 [1846]).

${ }^{40}$ In 1847 Feuerbach wrote, "we eliminate with the evils of the earth [also] the fortresses and foundations of heaven. Every improvement of justice on earth is an impairment of heavenly justice; every gain for this world (Diesseits) is a deficit for the Beyond (Jenseits). One stands or falls only at the cost of the other": Ludwig Feuerbach, "Über meine 'Gedanken über Tod und Unsterblichkeit'," in Sämmtliche Werke (Stuttgart: Fr. Frommans, 1903 [1847]), 201.
} 
Man should thus give up Christianity, first then does he complete and reach his purpose, first then does he become a human; because the Christian is not a human, but rather "half animal and half angel." First ... when man is everywhere man and knows himself to be man; when he no longer wants to be more than that which he is, can or should be; when he no longer sets himself an unreachable, fantastic goal opposed to his nature and purpose, the goal of becoming a god, i.e. an abstract, fantastic being, a being without body, without flesh and blood, without sensual drives and needs; first then is he complete, first then is he a complete man, then there is no gap more in him, where the Beyond could find a toehold (sich einnisten). ${ }^{41}$

In order to become this "complete man," Feuerbach believed that the human being must understand himself entirely within nature and within matter; any extension into the Beyond would rob the spirit of its identity with corporeal being.

The comparison of the writings of Fechner and Feuerbach allows for two initial conclusions regarding the problem of natural science and the Beyond. First, it indicates that nineteenth-century adherents of natural scientific empiricism favored monist solutions to the problem of death, that is, they believed that death marked a reconfiguration rather than an absolute severance of the unity of matter and spirit. Fechner described a world in which death led spirits into another dimension that was still of this world, whereas Feuerbach argued that spirit never left its connection to matter in this world. Second, in contrast to their works of the 1830s, the later texts of Fechner and Feuerbach show a heightened awareness of the growing conflict between belief and disbelief. By 1846, Feuerbach no longer saw the Beyond as a fiction that merely vanishes in the course of the development of consciousness but as a central pillar of an oppressive system of domination. Fechner, for his part, stated that one of his aims in writing Zend-Avesta was to provide the theologian "a few scientific weapons" to "support the demands of his faith." 42 Materialist monists and spiritualist monists were conscious of one another as belonging to antagonistic camps. ${ }^{43}$

\footnotetext{
${ }^{41}$ Ibid., $161-162$.

${ }^{42}$ Fechner, Zend-Avesta I, v.

${ }^{43}$ Opposition to materialism and Freigeistigkeit was an explicit part of the interest in spiritualism that spread in Europe in the 1850s. A former Catholic priest and champion of spiritualism asked: "Why do the Christian heathens and Jews rage and fume so very much against the belief in the revelations of spirits? In order to ban the terrible spook of superstition? As though it were superstition, if we see, hear, and experience a remarkable phenomenon of nature, perceive [it] with all senses, examine [it] with reason and science and draw conclusions from that! If that is superstition, then all of our great physicists, geologists, astronomers, chemists, physicians, and natural scientists are stupid, superstitious people.... I demand not faith, but investigation and examination alone." This book is appropriately subtitled Scientific and Substantive Defense of the Science of Spirits with Essential Conclusions about the Beyond: Franz Ammann, Meine
} 
Fechner found a positive reception among the life reformers and Bohemian artists who turned from naturalism to neo-romanticism in about 1900 and who played an important role in the founding of the Monist League. ${ }^{44}$ This, however, was an elite avant-gardist monism. Feuerbach's philosophy found a much wider readership. Most radical democrats, socialists, and organized Freigeister embraced Feuerbach's diesseitig humanism and had little tolerance for esoteric, spiritualist monism. To explain Feuerbach's popularity and to understand the conditions under which he made the transition to a polemical negation of the Beyond in the mid-1840s, one can usefully turn to the structures of religious and political dissent best exemplified at that time by Free Religion.

\section{Dissent And the Liquidation of the Beyond}

The key theological development within early Free Religion was the displacement of Christian rationalism by natural scientific monism. Although this was an uneven process that was never completed in several congregations, for many Free Religionists this transformation took place within an extremely short time period between roughly 1845 and 1850 .

A forceful illustration of the rapidity of the transition to monism can be won by comparing two texts penned by Karl Schrader (1795-1875), a Protestant pastor who became the preacher of the Free Religious Congregation in the town of Holzhausen near Bielefeld. In 1832 Schrader had published a biography of the Apostle Paul that posited the promise of "a new supernatural (überirdisches) life" as the very essence of Pauline teaching. In a rationalist fashion, Schrader identified the sleeping "free spirit" that Paul awoke in his followers with reason. When God's laws and the human spirit met in "infinite complexity and beauty," they could produce nothing but the "true and good and beatifying." This prepared the coming of the "kingdom of heaven on earth," although "the kingdom of the world perishes.",45 According to this rationalist view, striving for the Beyond did not contradict the operations of the free spirit and of reason.

offene Nothwehr oder: Wissenschaftliche und gründliche Vertheidigung der Geisterkunde mit wesentlichen Aufschlüssen über das Jenseits (Zurich: 1856), vii.

${ }^{44}$ See the representative essay "Fechner" by Wilhelm Bölsche, one of German's most renowned science popularizers and co-founder of the monistic Giordano Bruno League for Unified Worldview, in Hinter der Weltstadt (Leipzig: Eugen Diederichs, 1901), 259-347. See also Monika Fick, Sinnenwelt und Weltseele: der psychophysische Monismus in der Literatur der Jahrhundertwende (Tübingen: Niemeyer, 1993).

${ }^{45}$ Karl Schrader, Der Apostel Paulus: Zweiter Teil, oder das Leben des Apostels Paulus (Leipzig: Christian Ernst Kollmann, 1832), 371. 
About 1850, Schrader published the first volume of Free Religion: A People's Book. This book retained his earlier belief in the natural drive of man toward self-perfection and communion with the infinite. However, Schrader now saw the Pauline faith in an afterlife as the greatest obstacle to these goals: "As long as man thinks of the infinite outside of the world, or next to the world, or penetrating the world, but differentiates or divides the world, even the smallest particle thereof [from the infinite], he will have in this particular infinity nothing but an empty illusion, an infinite nothing into which he will fall with all that from which he has separated himself.",46

This text, like the volumes that followed it in the 1860 s and $1870 \mathrm{~s}$, was a lengthy, popular scientific enumeration of the natural world, in which there was no place for the precepts of Christianity. Mobilizing the law of the retention of energy recently popularized by Hermann von Helmholtz and others, Schrader concluded that "the infinite universe contains all that is; there is nothing outside of it, nothing can disappear from it ... [or] enter into it; it is the necessarily existent, that which has always been and always remains and the never depleting, the never growing, the infinite everything in its entirety." 47 Such pedantic repetition of the essential assumptions of scientific materialism drove home Schrader's new conviction that the universe was a unified, saturated, self-organizing space in which, to use Feuerbach's phrase, "the Beyond" cannot "find a toehold." Free Religionists like Schrader portrayed their newfound belief as having emanated from the truth of scientific discovery. Historians of Free Religion must, however, not fall victim to the same idealist interpretation. As the previous section demonstrated, natural science did not per se precipitate the completely negative critique of the Beyond. This development depended on the structures of dissent that emerged in the crucible of the German Vormärz.

Faith in a "higher kingdom of God beyond (jenseits) the grave" was one of the few tenets of Christian dogma that the Protestant dissidents, who became known as the "Friends of Light," were willing to accept as binding when they began to organize in 1841 and $1842 .{ }^{48}$ Even as their most radical figure, the Hallenese minister G. A. Wislicenus, challenged the Bible's status as revelation in the shocking speech of 1844, "Scripture or Spirit," he did

\footnotetext{
${ }^{46}$ Karl Schrader, Die Freie Religion: Ein Volksbuch (Die Größe des Weltalls) (Holzhausen: Selbstverlag, n.d. [ca. 1850]), I:24.

${ }^{47}$ Ibid., 23.

${ }^{48}$ This mention of life "beyond the grave" is found in the list of ten theological tenets proposed in 1842 by the leading voice of the Protestant Friends of Light, Leberecht Uhlich. Because of his populist style and defense of religious freedoms, Uhlich became known as the "Saxon O'Connell” after the Irish politician. After his defrocking in 1847, Uhlich became the preacher at Germany's largest Free Congregation in Magdeburg: cited in Heinrich Pröhle, Feldgarben: Beiträge zur Kirchengeschichte, Literaturgeschichte und Culturgeschichte (Leipzig: Gustav Gräbner, 1859), 32.
} 
not directly pose the question of existence of God or the Beyond. ${ }^{49}$ The polemical negation of the Beyond fully emerged only after the German monarchies and their ecclesiastical authorities began to force the dissidents out of the state churches, a process which began in earnest in 1845 .

The feedback loop of state and clerical suppression and the radicalization of critique played out most clearly and with greatest historical impact in Prussia, the largest Protestant state of Germany. Supporting dissident religious rights in the name of "Protestant freedom" was an important stage in the early organization and articulation of Prussian liberalism. In August 1845, for example, the Berlin Magistrate delivered a petition to the king that publicly identified itself with the cause of the Friends of Light in their struggle against conservative Pietists, whom the king was known to favor. ${ }^{50}$ In an effort to end such opportunities for insubordination within his church and state, Friedrich Wilhelm IV issued the Religionspatent, or "Dissidents' Law," of March 30, 1847, which forced Protestant liberals to decide between conformity to the state church or autonomy in the "Free Congregations." Most liberal elites chose to stay in the church, leaving the new sect to become an organizational form of the radical members of the urban middle and lower-middle classes. ${ }^{51}$ No longer compelled to seek compromise within the church or adhere to moderate liberal conventions, the leaders of the Free Congregations increasingly uttered statements that openly contradicted Christianity. ${ }^{52}$

\footnotetext{
${ }^{49}$ Gustav Adolph Wislicenus, Ob Schrift? Ob Geist? Verantwortung gegen meine Ankläger, 3rd improved ed. (Leipzig: Otto Wigand, 1845). After this publication of his speech, an ecclesiastical court called on Wislicenus to recant in the spring of 1845 . When he refused, he lost his right to preach in the Protestant Church. On Wislicenus and the Friends of Light, see Robert Bigler, The Politics of German Protestantism: The Rise of the Protestant Church Elite in Prussia, 18151848 (Berkeley: University of California Press, 1972), 187-230, 233-261.

${ }^{50}$ The Protestant liberal politician and literary scholar Rudolf Haym (1821-1901), who had been an early supporter of the Friends of Light in Halle, later recalled that "church liberalism was the training ground for political liberalism": cited in Dieter Langewiesche, Liberalism in Germany, trans. C. Banerji (Houndsmills and London: Macmillan, 1988), 27. For the text of the magistrate's petition to the king, see anon., Die Theologie des Berliner Magistrats (Münster: J. H. Deiters, 1845).

${ }^{51}$ Brederlow, Lichtfreunde, $49-81$, n. 81. According to participant Rudolf Haym, only a minority of the Halle Friends of Light joined the "adventurer" Wislicenus to "make the leap into emptiness": cited in Bigler, German Protestantism, 237. On the "Religionspatent" of March 1847, see Martin Friedrich, Die preußische Landeskirche im Vormärz: Evangelische Kirchenpolitik unter dem Ministerium Eichhorn (1840-1848) (Waltrop: Hartmut Spener, 1994), 387-420.

${ }^{52} \mathrm{At}$ the first conference of the Free Congregations in Nordhausen in 1847, the more radical congregations of Halle, Marburg, and Hamburg agreed "that today's worldview and lifeview (Welt- und Lebensanschauung) is a new one, which can no longer be called Christianity." The January 1848 statutes of the Free Congregation in Marburg also invoked "worldview" as the core term for the new belief: "Our religion, i.e. the idea that animates us, comprises [the following]: to found a united humanity in which each individual can bring his essence to greater perfection through the power of the spirit [and] on the basis of a unified worldview (Weltanschauung)": both citations in Paletschek, Frauen, 102.
} 
A further boost to the proliferation of the negative definition of the Beyond came with the Revolution of 1848, when many dissidents felt that the hour had come for their congregations to export their fraternal structures and humanist teachings into German society as a whole. Numerous Free Religious preachers were elected to the Frankfurt and Berlin Revolutionary parliaments. At Frankfurt, the Deutschkatholiken concentrated in the democratic-left "Deutscher Hof," where - under the leadership of Robert Blum - they had an early decisive influence. In the Prussian Parliament, the Friends of Light preachers Leberecht Uhlich of Magdeburg and Eduard Baltzer of Nordhausen sat with two deutschkatholisch preachers from Silesia in the Commission on Religion and Church. ${ }^{53}$

Amid the political radicalization, several dissenting publications emerged with a partisan agenda that attacked the rationalism still adhered to by many of the Deutschkatholiken and Friends of Light. One such journal was For Free Religious Life, published by the Breslau preachers Theodor Hofferichter and Ferdinand Kampe in 1848 and 1849. Both men were politically engaged radicals and advocates of what they referred to as "the humane religion." 54 Kampe used the metaphor of the parliament to describe growing differences between the main branches of Deutschkatholizismus. "Conservative rationalism" sat on the right, "speculative" theology mediated in the Left Center, and "the humane current" sat "on the Left ... with ranks closed around the unity of its unconcealed, strong principle." $" 55$ The same struggle against Christian rationalism was taking place among the former Protestants. In a theological dispute in the Magdeburg Free Congregation, the young preacher Heinrich Sachse complained that his elder colleague Leberecht Uhlich had "proclaimed with painful naiveté faith in God, virtue, and immortality." According to Sachse, this "confession of "the old rationalism" based on the "old "Enlightenment theology" failed to take into account that the rationalist movement "has undergone and is still undergoing the separation process between belief in the supernatural and the science of the natural, between belief in the godhead and the knowledge and recognition of humanity, between the rule of religion and the rule of ethics (Sittlichkeit).",56

The separation between humanism and rationalism was given a more polemical twist in a poem published in a September 1848 issue of For Free Religious Life by

\footnotetext{
${ }^{53}$ In the Prussian provinces of Saxony and Silesia alone, ten leading members of the Free Religious movement were elected to the Prussian Parlament: Brederlow, Lichtfreunde, 86. See also Graf, Deutschkatholizismus, 121.

${ }^{54}$ Hofferichter was an early promoter of natural scientific monism. Kampe, who became the movement's best historian, dated the beginning of "the humane religion" back to 1846 and 1847. Ferdinand Kampe, Das Wesen des Deutschkatholizismus, mit besonderer Rücksicht auf sein Verhältniß zur Politik (Tübingen: Ludwig Fues, 1850), 72.

${ }^{55}$ Ibid., $72-73$.

${ }^{56}$ Heinrich Ernst Sachse, Drei Vorträge: Mit einem Vorworte über den Unglauben an 'Gott, Tugend und Unsterblichkeit' (Magdeburg: E. Fabricius, 1852), 4-5.
} 
the candidate of theology and later deutschkatholisch preacher Phillip Krebs. This poem, ironically titled "Reconciliation," can be read against the passage from the rationalist poem Reason's Glimpses into the Beyond cited above:

Diesseits and Jenseits! Away with any bridge!

We need no bridge more, nor ferry!

'Whole!' is the slogan! 'Whole! Of a single piece!'

And all half measures be now discarded!

...

Diesseits and Jenseits! - let the pact be torn,

Let the weak be made strong and the strong weak!

Each now stands on his own feet,

And each name his, what he has achieved! ${ }^{57}$

It is significant that this demand for the active elimination of the Beyond appeared during the autumn crisis of 1848 , when the revolution entered a more violent, divisive phase. It was at this time that radicals, including many Free Religious leaders, decisively broke ranks with the liberal-dominated Parliament in Frankfurt that favored constitutional monarchy. Unwilling to make concessions to the old regime, the democrats moved toward revolutionary violence. The metaphor of the demolished bridge between Jenseits and Diesseits could stand for the complete theological separation of humanism from Christian rationalism as well as the break between radicals and liberals.

For conservative Protestant leaders, the Revolution confirmed in their minds the connection they had long seen between political and religious dissent. The influential Berlin editor of the Protestant Church Newspaper, Ernst Wilhelm Hengstenberg, had not tired of attacking what he saw as the latent atheism of the Friends of Light since their emergence. ${ }^{58}$ However, with the Revolution, he found that this atheism had broken through to a new level. In June 1848, his paper interpreted the course of the Revolution as follows: the "Radicals" had "desecrated all of Germany by ripping it from the Christian Church and enslaving it under the dominion of Jews, Deutschkatholiken, pantheists und atheists," who sat in the Parliament in Frankfurt. Hengstenberg feared "that we are on the threshold of a growing anti-Christian world power." 59

\footnotetext{
${ }^{57}$ Für freies religiöses Leben: Materialien zur Geschichte und Fortbildung der freien Gemeinden, insbesondere der freien katholischen, 1:10 (8 September 1848), 78.

${ }^{58}$ Already in 1844 Hengstenberg had shown an acute awareness of the larger political implications of radical religious dissent when he wrote: "It is natural that this Jacobinism in the field of the Church will sooner or later declare itself publicly against the state. For [if] someone ceases to owe obedience to God's word, i.e. to God, how shall he remain the servant of worldly authority?" cited in Hans-Jürgen Gabriel, "Im Namen des Evangeliums gegen den Fortschritt. Zur Rolle der 'Evangelischen Kirchenzeitung' unter E.W. Hengstenberg von 1830 bis 1849," in Beiträge zur Berliner Kirchengeschichte, ed. Günter Wirth (Berlin: Union Verlag, 1987), 166.

${ }^{59}$ Gabriel, "Im Namen," 171-173.
} 
The rapidity with which the Beyond was given a completely negative valuation indicates the importance of the ecclesiastical, social, and political ruptures in the years between 1845 and 1848. These ruptures made possible and desirable the fusion of radical humanism and scientific empiricism in pantheistic or atheistic creeds. At a time when overt advocacy of atheism was still largely taboo, the criticism of the Beyond was one of the chief weapons used by radical humanists to attack the legitimacy of any traditional authority, in particular the divine right of monarchy. ${ }^{60}$ It was a simple, effective form of ideological criticism that allowed those who wielded it to claim empirical reality and common sense for themselves. They associated Diesseits with masculine autonomy, brotherly love, the future, rectitude, and morality. Jenseits signified illusion, ignorance, and the willing collusion between weakness with authority, a relationship that was depicted stereotypically through images of the priest and the pious woman. In their sermons, dissident preachers told their followers that popular scientific illumination would unmask the enemy's founding illusion and then sweep in to fill the vacuum. This was an attractive prognosis for socially marginal urban groups, who identified with modernity but had little real political or economic power. $^{61}$

\section{The Secularist Resistance to Secularization}

Free Religion has been the object of some interest for Protestant church historians. In 1901 theologian Paul Drews begrudgingly acknowledged some of the Free Congregations as radical embodiments of the principle of Protestant freedom. In his 1937 history of liberal Protestantism, Walter Nigg recognized the theology of Ludwig Feuerbach and D. F. Strauss and the religious impulses of the original Friends of Light as the zenith and at the same time the crisis point of progressive Protestantism. For both of these church historians, however, the subsequent fusion of left-Hegelianism with

\footnotetext{
${ }^{60}$ French and English observers of the literature of the revolution in Germany alerted their readers to the special significance of "Jenseits." A British reviewer found it consistent that the "sects" of French and German radicals who assert the "perfectibility and potential omnipotence of mankind" also "in the interest of their paradise here, ... reject what the Germans among them significantly call das Jenseits-the Beyond": Anon. "German Socialism," in The North British Review, 21: 22 (1849), 406-435, n. 414. A French reviewer of German historical criticism found that "the writings of the young school are abrupt, rude, realist, materialist, denying heartily and absolutely the Beyond (das Jenseits), that is to say the suprasensible, the religious in all its forms, declaring that it is an abuse of man to make him live in that fantastic world": E. R., "Les Historiens Critiques de Jésus," in La Liberté de Penser 13 (1849), 437-470, n. 439.

${ }^{61}$ I explore these dynamics more deeply in Todd Weir, "Towards a History and Sociology of Atheist Religious Community: The Berlin Free Religious Congregation, 1845-1921," in Die Gegenwart Gottes in der Modernen Gesellschaft, eds. Lucian Hölscher and Michael Geyer (Göttingen: Wallstein 2006), 197-229
} 
natural science led to an excess of negation and a "degeneration" into what Nigg called the "religious cretinism" of monism. ${ }^{62}$ Like Nigg, Drews believed that natural scientific monism could not maintain a religious system, "for a religion that wants to be everything but communion with God and a relationship to a transcendent is a knife without a blade."63

Some histories of early Free Religion have similarly suggested that the movement fell victim to the logic of its own secularizing message. ${ }^{64}$ This poses an important question for the history of the term "Jenseits": did materialism not ultimately turn on and undermine the radical humanism and pantheism of the "religion of Diesseits"? In other words, did natural scientific empiricism contribute not just to the disenchantment of Christianity and Judaism but of humanism as well? While it is true that Free Religion declined as a result of massive state repression in the $1850 \mathrm{~s}$, new freigeistig organizations continued to emerge until 1933 (and even after this date, if one includes völkisch-freigeistig associations formed under National Socialism). Hence the popular association of natural science with the "religion of Diesseits" remained important longer than has generally been assumed. The manner in which a secularist movement resisted the secularizing impetus of its own natural scientific materialism requires closer investigation. This apparent paradox is explained in part by monist assumptions that enabled materialism to provide a basis for religious transcendence. In part, the resistance to secularization resulted from the long-term continuities in the social, political, and ecclesiastical structures of dissent that had first constituted Free Religion and the critique of Jenseits.

The historian of popular science Andreas Daum has argued that materialism and spiritual pantheism formed the opposing poles of the popular scientific community. ${ }^{65}$ As useful as this distinction is, it is important to recognize that the harsh words spoken by the more spiritual Freigeister against "materialism" were largely polemical. Philosophically speaking, materialism

${ }^{62}$ Paul Drews, "Die freien religiösen Gemeinden der Gegenwart," Zeitschrift für Theologie und Kirche 11 (1901): 484-527. According to Nigg, the expulsion of the Friends of Light led to a cautious self-censoring of theological criticism within the Church, which he saw as the birth defect of modern Protestant liberalism: Walter Nigg, Geschichte des religiösen Liberalismus: Entstehung-Blütezeit-Ausklang (Zurich and Leipzig: Max Niehans, 1937), 367.

${ }^{63}$ Paul Drews, "Die freien religiösen Gemeinden," 500.

${ }^{64}$ Most historians of Free Religion have ended their accounts with the movement's sharp decline during the 1850s. By describing the thrust of deutschkatholisch dissent as a translation of rationalist religious dissent into political consciousness, historians Hans Rosenberg and Friedrich Wilhelm Graf implicitly placed the movement's ultimate decline within a secularization paradigm. More recent studies by Sylvia Paletschek and Andreas Holzem have shown, by contrast, that state repression in the 1850 s was the prime cause of the shrinkage of the movement (see n. 12 for titles).

${ }^{65}$ Andreas Daum, "Naturwissenschaften und Öffentlichkeit in der deutschen Gesellschaft. Zu den Anfängen einer Populärwissenschaft nach der Revolution von 1848," in Historische Zeitschrift 267 (1998), 57-90, esp. 81-85. 
and pantheism were two sides of the same monist coin. ${ }^{66}$ Even the most notorious of the "materialists" of the 1850 s, Karl Vogt, Jacob Moleschott, and Ludwig Büchner, supported some type of monist sacralization of nature. The absolute reduction of all phenomena to "Force and Matter," the title of Büchner's famous work of 1855, was meant to destroy once and for all the metaphysical systems of theology and philosophical idealism. "Force and Matter" was, however, also a metaphor for the unity of spirit and body, of culture and nature, as well as of transcendence and immanence. Thus, the deutschkatholisch preacher Carl Scholl was essentially correct when he defended materialism as the basis of radical Free Religion in $1876 .{ }^{67}$

Freigeistig monism contained its own theory of transcendence, an early articulation of which is found in "The Temple of Unity," an article published in Hofferichter and Kampe's journal in February 1849. The author began by arguing that the organizing spirit of the universe (Geist) was rooted in "substance" or the "originary foundation (Urgrunde) of being." Substance was formed of two parts, "substrate, or the foundation of matter," and the "originary force (Urkraft) as the foundation of formation." All physical and spiritual phenomena were different manifestations of "an infinitely great movement," which is "the life of substance... Thus spirit and matter are eternally united, like originary force and substrate: the universe is the totality of their essence and their appearance." 68 From this universal monistic foundation, the author went on to derive the value of humanity. Physically the human is a "formation of global substance" like any other life form, but spiritually, the human is the "individual expression of the self-conscious

\footnotetext{
${ }^{66} \mathrm{My}$ interpretation of the essential epistemological identity of naturalistic monism with materialism agrees with that of German philosopher Rudolf Eucken, who called the monists' claim to weigh both spirit and matter equally a fallacy. Natural scientific monists like Ernst Haeckel may have quoted Goethe and Spinoza, but they nonetheless ultimately explained spiritual and cultural phenomena through their materialist systems: "Monism," in Encyclopaedia of Religion and Ethics, ed. James Hastings (New York: Scribner and Sons, 1908-1926), 808810. Against this view, see Niles Holt, "Ernst Haeckel's Monistic Religion," Journal of the History of Ideas 32 (1971): 265-280. Two other authors, who have stressed divergences within monism rather than its overall coherence, are Gangolf Hübinger, "Die monistische Bewegung. Sozialingenieure und Kulturprediger," in Kultur und Kulturwissenschaften um 1900, eds. Gangolf Hübinger, et al. (Stuttgart: Steiner, 1997), 246-259; and Olaf Breidbach, "Alle für Eines. Der Monismus als wissenschaftsgeschichtliches Problem," in Monismus um 1900, ed. Paul Ziche (Berlin: Verl. für Wiss. und Bildung, 2000), 9-22.

${ }^{67} \mathrm{Scholl}$ referred to materialism as "the active catalyst (treibende Ferment) that is destined to lead us out of the dream life of the past and into the full, real life of the present, ... out of the period of Unnature - of old and modern barbarism and hypocrisy - and into [the period of] Nature, of truth, of true, actual education (Bildung), out of the condition of malignant yearning for heaven and Jenseits-fanaticism into that of healthy practical-beautiful human life and of satisfaction with this world (Diesseits)": From "Noch einmal der "Materialismus,"” in: Es werde Licht! Beiträge zur Förderung der Religion der Humanität von Carl Scholl 7:8 (May 1876): 113-124, n. 124.

${ }^{68}$ K. B., "Der Tempel der Einheit," in: Für freies religiöses Leben, vol. 2, no. 6, 9 Feb. 1849, $37-41$, citations on 38,39 .
} 
originary force." This makes the human being the highest form of organization of universal energy and the vehicle through which nature becomes conscious of itself. Vice versa, only through a correct understanding of his natural being can the human come to self-consciousness:

Sufficient in himself, man thus finds his place as complete man. He does not look up to a higher Beyond (Jenseits); he has the highest in himself, as soon as he recognizes his own essence in its connection with the universe and correspondingly this great totality as his own inner essence. The universe is God to him ...; thus he finds himself in God and God in him; he speaks: we live, act, and exist therein, and he is conscious of his godly nature. ${ }^{69}$

This passage indicates the novelty of the Free Religious division of the sacred and the profane. By inverting the order of Christianity, which places the sacred in the transcendent and the profane in the material, Free Religion instead calls the profane sacred. The term "Jenseits" now depicts the formerly sacred sphere as an illusion.

Whether they thought of themselves as materialists, pantheists, atheists, or humanists, monists found in the idea of universal "substance" something of a functional equivalent for the transcendent plane. This did not, however, resolve the dilemma that, according to Max Weber, faced all religions, namely, how to manage the "conflict between empirical reality and the conception of the world as a meaningful totality."70 Transcendental religion relies on the absolute difference between the material world and the unseen world of God or spirits to maintain its totality. Because Free Religion posited the totality in the profane, the senselessness of everyday reality threatened to undermine its ability to provide spiritual compensation and meaning.

Like the modern political ideologies, Freigeistigkeit recouped this loss of the sacred by placing its fulfillment in the future. The promised totality would be the outcome of grand social conflicts and battles for the souls of believers. Given its primarily spiritual orientation, freigeistig monism relied heavily on the ongoing rhetorical liquidation of the Beyond in order to maintain the sacral qualities of Diesseits. Jenseits, in other words, was not a theme that

\footnotetext{
${ }^{69}$ The author of the "Tempel der Einheit" described how nature compensates humans for death. First, death is redefined. On the physical level there is no death in the closed system of a saturated universe, only "a necessary transformation of organization." Second, on the level of the spiritual organization, the "individual's spirit lives on in his results, his fellow men, maybe in his children, and thus his spirit does not depart as personality in higher spheres-it had already lived and acted in the general spirit of the universe!" This essentially summarizes the weak afterlife that Freigeistige speakers were still offering their followers at graveside ceremonies well into the Weimar Republic, that is, that the deceased had contributed their bodies, deeds, and spirits to the material and cultural humus of future human progress: ibid., 40.

${ }^{70}$ Max Weber, "The Prophet," in Max Weber, On Charisma and Institution Building, trans. E. Fischoff (Chicago: University of Chicago Press 1968), 253-267, 267.
} 
Freigeister could ever overcome; it had to be continually negated in order for a religion of Diesseits to exist.

This dependence of Diesseits on Jenseits is revealed in the frequent invocation of the phrase "the old and the new Weltanschauung" for Christian theology and natural scientific monism, respectively. The Friend of Light Eduard Baltzer chose this as a title for his collected sermons in the 1850s. Baltzer also worked this comparison into sermon passages like the following: "The positive can only be found in the real world, in the heavens that we are in the midst of, on the earth that gave birth to us, in the hereand-now (Dieseits), where we might say-given that there is no Beyond (Jenseits) - life's revelation is [found]. " ${ }^{, 71}$ A more explicit connection between the negation of the sacred in Jenseits and its recuperation in Diesseits was made in the sermon of Theodor Hofferichter in Breslau on January 8, 1860. "The eternal, infinite world that fills everything," he told his congregation, "has no room for a second heavenly world, [no room] for a personal God, to which Christian and Jew pray." He then denied that the Free Religious were without God: "Look there! Our godhead is much higher, more powerful and effective than all gods in which people have believed till now. Our godhead is no creation of human fantasy, no simply imagined being, our God is no powerless, dead being ... our God is a living God, it is eternal life itself, in which and through which we too live and exist." ${ }^{, 72}$

The critique of the Beyond reveals the dual nature of the secularist offensive. It sought to secularize and to create a new religion of Diesseits at the same time. $^{73}$ This duality of disenchantment and substitution manifested itself in the manner in which each new freigeistig movement announced the demise of its predecessor. When the former left-Hegelian theologian David Friedrich Strau $ß$ advised the readers of his 1872 bestseller that they would have to stoically accept natural scientific monism as a "new faith" and forego churches, he cited the Berlin Free Religious Congregation as proof of the absurdity of founding an association to abolish associations. There would be no monist church. ${ }^{74}$ At the same time, however, Strauß's construction of

\footnotetext{
${ }^{71}$ Hofferichter cited Baltzer in his sermon of 23 October 1859, "Zurück zur Natur," in Theodor Hofferichter, Gott und Welt: Freireligiöse Vorträge (Breslau: Selbstverlag, 1862), 37.

${ }^{72}$ Ibid., 77.

${ }^{73}$ Sociologist Ulrich Oevermann sees atheism as a step of separation from monotheism before a more secular position of religious indifference is reached: see his article "Strukturelle Religiösität und ihre Ausprägungen unter Bedingungen der vollständigen Säkularisierung des Bewusstseins," in Atheismus und religiöse Indifferenz, eds. Christel Gärtner, Detlef Pollack and Monika WohlrabSahr (Opladen: Leske \& Budrich, 2003), 339-387.

${ }^{74}$ David Friedrich Strauß, Der alte und der neue Glaube. Ein Bekenntnis, 2nd ed. (Leipzig: S. Hirzel, 1872), 7, 296-297. The English translation by M. Blind appeared as The Old Faith and the New: A Confession (London: Asher and Co., 1874). For a critique of the substitution model of secularization, see Todd Weir, "The Secularization of Religious Dissent: Anticlerical Politics and the Freigeistig Movement in Germany 1844-1933," in Religiosität in der
} 
"The Old Faith and the New" - the title of his book-relied on the dichotomy of Jenseits/Diesseits. In this way he replicated the freigeistig structures, albeit outside the institutional confines of Free Religion. Here too, natural scientific monism and atheist humanism were infused with religious meaning.

The freigeistig liquidation of the Jenseits remained an ongoing process necessary to sacralize Diesseits and prevent its erosion into the mundane.$^{75}$ It also linked the internal arrangement of the sacred in monism to the external conflicts between dissenters and the confessional order dominated by rival state churches. The confessional conflicts, in which secularism found a fixed position, were ultimately resolved, first by murderous force by the National Socialists and then by the postwar division of Germany and the ideological exigencies of the Cold War. Only then were the structural grounds weakened that had sustained the reproduction of monism and the critique of the Beyond for a century.

\section{CONCLUSION}

The history of the term "Jenseits" opens a window onto the emergence of secularism and its relationship to secularization. The proliferation of the term in religious discourse in the early 1830 s coincided with the secularizing pressure of scientific empiricism. However, neither the triumphs of German natural science nor the further development of left-Hegelian religious criticism alone accounted for the rapid semantic transformation of the term "Jenseits" in the late 1840s. Science popularizers may have claimed that their highly polemical depiction of the Beyond as an illusion followed from the simple act of reading out of the Book of Nature. Behind this claim, however, lay structures of political and religious dissent that developed into what became a clearly secularist movement. Secularists actively deployed the opposition of Jenseits/Diesseits as one of their chief weapons in the struggle with the state churches and the reigning social and political order.

Free Religion, which emerged together with the radical critique of the Beyond, reveals the ambiguity of secularism. One of its expressed aims was the secularization of the state, schools, and public sphere. Such secularization was, however, always combined with a call to a religion of Diesseits. The void of the Beyond proclaimed by Free Religious preachers before their congregations

säkularisierten Welt, ed. Christel Gärtner, Manuel Franzmann, and Nicole Köck (Wiesbaden: VSVerlag, 2006), 155-176.

${ }^{75}$ The ongoing importance of the opposition of Jenseits/Diesseits to the constitution of Freigeistigkeit is shown by the choice of Diesseits as the title of the popular journal of the contemporary German Freethinkers, who renamed themselves the Humanist Association of Germany in 1990 . 
therefore stood less for the death of religion than for the introduction of nature, humanity, and even atheism into the religious sphere.

What is the overall significance of these findings about the religiosity of secularism to the history of modern religion and thought? A great deal, if we follow Charles Taylor. In his recent book A Secular Age, Taylor challenges the idea that secularization has meant an evaporation of religiosity. Instead, the overarching framework and underlying assumptions in which religiosity operates have been reconfigured. According to Taylor, one of the crucial transformations marking the end of the Christian and the beginning of our secular age was the move "from a world in which the place of fullness was understood as unproblematically outside of or 'beyond' human life, to a conflicted age in which this construal is challenged by others which place it (in a wide range of different ways) "within' human life." 76

It is fitting that Taylor uses the opposition "beyond/within" to make his case, for this essay has shown that these terms were generated by a secularism that was both secular and religious. However, Taylor uses "beyond" in inverted commas, which indicates that the term's meaning has changed yet again. The term has become neutralized and lost its polemical qualities. The secular age Taylor surveys from the vantage point of 2007 is not the same as the age of secularism, when "Jenseits" was used to attack the clerical order and to infuse "Diesseits" with great hope. In Germany, this age coincided with the period in which freigeistig positions helped define the political and religious fields, that is, in the century after 1845 .

Three preliminary explanations can be offered as to why secularism should withstand secularization during this period. First, monism retained the ability to offer a nominally secular form of religious transcendence in the guise of radical humanism and natural scientific Weltanschauung. Monism emerged together with Free Religion in the 1840s and came to dominate Freigeistigkeit by the 1860s and 1870s. Despite growing attacks from university scientists and liberal philosophers after 1900, natural scientific monism remained a central religious, philosophical, and political discourse in Germany at least until the destruction of the National Socialist regime in $1945 .{ }^{78}$

Second, the freigeistig organizations mentioned in this essay were but the most prominent examples of a much wider spectrum of secularist activity. In 1932

\footnotetext{
${ }^{76}$ Taylor, A Secular Age, 15

${ }^{77}$ The fate of Freigeistigkeit between 1933 and 1945 has yet to be thoroughly researched (see literature in n. 13). My own research would suggest, however, that despite the National Socialist attestations of their adherence to "positive Christianity," the sacralization of the German race under the National Socialists might be loosely described as völkisch monism.

${ }^{78}$ For an investigation of the fate of popular science and the monist worldview in East Germany after 1949, see Igor Polianski, "Das Rätsel DDR und die 'Welträtsel': Wissenschaftlich-atheistische Aufklärung als propagandistisches Konzept der SED," in Deutschland Archiv 40:1 (2007): 73-82.
} 
a Protestant theologian urged fellow ministers to recognize the freethinkers "as the crest of a wave in the sea that has risen from humanity against God's claim to governance." More important than the claim to natural scientific empiricism, he argued, was the shared "will to humanity and to this-worldliness (zum Menschen und zum Diesseits).,"79 Science popularization, monism, and anticlericalism were integral parts of the republican and socialist milieus, as well as the life reform, pacifist, and radical women's movements. Through the critique of Jenseits, these movements helped carve out a secularist position in the religious field of Germany that was at the same time a secularizing opposition and a quasi-confession that competed for adherents and legal rights with the state churches. ${ }^{80}$

Third, the ongoing recrudescence of monist theories, freigeistig organizations, and satirical invocations of "the Beyond" in public debate points to continuities in the overall structures in which secularist dissent took place. These included, in a narrow sense, the existence of state churches and clerical oversight of education and, in a wider sense, religious participation in the polarized political field. The particularities of the German religious constitution and the persistence of some of its key structures even after the fall of the monarchy in 1918 may help explain why "das Jenseits" could develop and retain an explosive force in Germany that its semantic equivalents in the other European languages failed to achieve. ${ }^{81}$

\footnotetext{
${ }^{79}$ Hermann Waldenmaier, "Weltanschauliche Grundlage," in Freidenkertum und Kirche: Ein Handbuch, ed. Carl Schweitzer and Walter Künneth (Berlin: Wichern, 1932), 4-5. This book was published by the Apologetic Central, the defensive arm of the Protestant Church founded to combat Freethought and neo-pagan movements. On the Apologetic Central, see Matthias Pöhlmann, Kampf der Geister: Die Publizistik der "Apologetischen Centrale" (1921-1937) (Stuttgart: Kohlhammer, 1998). The best work on the proletarian Freethinkers remains JochenChristoph Kaiser, Arbeiterbewegung und organisierte Religionskritik: proletarische Freidenkerverbände in Kaiserreich und Weimarer Republik (Stuttgart: Klett-Cotta, 1981).

${ }^{80}$ Todd Weir, The Fourth Confession. Atheism, Monism and Politics in the 'Freigeistig' Movement in Berlin 1859-1924 (Ph.D. diss., Columbia University), 2005.

${ }^{81}$ Anticlericalism and humanism were essential components in the development of European liberalism, radicalism and socialism. Secularism arguably had more lasting effects in Catholic countries like Italy and France than in Germany. While Freethought was an international movement, monism and Free Religion were particularly strong in Germany. Germany also became the center of European anticlericalism after World War I, only to be eclipsed by the state-sponsored Soviet League of the Militant Godless in the late 1920s. The best study of French Freethought is Jacqueline Lalouette, La Libre Pensée en France, 1848-1940 (Paris: Albin Michel, 1997). On Italian laicismo, see Guido Verucci, L'Italia laica prima e dopo l'Unita (Rome-Bari: Laterza, 1996). On the Russian case, see Daniel Peris, Storming the Heavens: The Soviet League of the Militant Godless (Ithaca, N.Y.: Cornell University Press, 1998). Comparative examinations of anticlericalism and confessional conflict in Europe can be found in René Rémond, ed., Special Issue: Anticlericalism, European Studies Review, 13:2 (1983); Christopher Clark and Wolfram Kaiser, eds., Culture Wars: Secular-Catholic Conflict in Nineteenth-Century Europe (Cambridge: Cambridge University Press, 2003); Heinz-Gerhard Haupt, ed., Nation und Religion in Europa: Mehrkonfessionelle Gesellschaften im 19. und 20. Jahrhundert (Frankfurt a. M.: Campus, 2004).
} 